\title{
TO THE HISTORY OF ONE TEXT: REGULATION ON THE ADMINISTRATION OF THE DON HOST OF THE 1860s
}

\author{
Artem Yu. Peretyatko \\ International Network Center for Fundamental and Applied Research, Sochi, Russian Federation; \\ American Historical Association, Washington DC, USA
}

\begin{abstract}
The article is devoted to the Regulation on the administration of the Don Host of the 1860s, which is still not found by historians. It is known that in 1862-1863 the work on this document has become scandalous, since Don public figures accused the Ministry of War of reluctance to take into account the real request of the Cossacks. As a result, electoral deputies were introduced to the Don Codification Committee, which had developed the Regulation.

The materials of Kh.I. Popov, one of the deputies, are stored in the State archive of the Rostov region. We've found manuscripts among these materials that contain criticism of the "project of basic principles of the Regulation, submitted to the deputies for consideration. We consider in detail this criticism, because it is important for the reconstruction of certain provisions of the text, submitted to the deputies. The analysis shows that the project of basic principles already had a compromise character, and did not comply with the liberal policy of the Ministry of War of the early 1860 s.

As a result of deputies' meetings, additional amendments to the project were made. The resulting text was sent to St. Petersburg in early 1864 . However, the imperial government did not accept this document, and the work on the drafting of the Regulation was de facto terminated.

Thus, the Regulation on the administration of the Don Host is a real text-phantom, and the search for its final version seems to be meaningless. Although the work on it had been formally conducted for almost a decade, only preliminary drafts were actually created at that time, and only some editions of the project of basic principles of the Regulation can be characterized by integrity and consistency.

Key words: Regulation on the administration of the Don Host of the 1860s, Don Codification Committee, Kh.I. Popov, D.A. Milyutin, reforms of the Don Cossacks of the 1860s.

Citation. Peretyatko A.Yu. To the History of One Text: Regulation on the Administration of the Don Host of the 1860s. Vestnik Volgogradskogo gosudarstvennogo universiteta. Seriya 4, Istoriya. Regionovedenie. Mezhdunarodnye otnosheniya [Science Journal of Volgograd State University. History. Area Studies. International Relations], 2018, vol. 23, no. 2, pp. 100-110. (in Russian). DOI: https://doi.org/10.15688/jvolsu4.2018.2.8
\end{abstract}

УДК 94(47).081

ББК $63.3(2) 522$

Дата поступления статьи: 25.12.2017

Дата принятия статьи: 28.02.2018

\section{К ИСТОРИИ ОДНОГО ТЕКСТА: «ПОЛОЖЕНИЕ ОБ УПРАВЛЕНИИ ДОНСКОГО ВОЙСКА» 1860-х ГОДОВ}

\footnotetext{
Артем Юрьевич Перетятько

\author{
Международный сетевой центр фундаментальных и прикладных исследований, \\ г. Сочи, Российская Федерация; \\ Американская ассоциация историков, г. Вашингтон, США
}

Аннотация. Статья посвящена до сих пор не найденному историками «Положению об управлении Донского войска» 1860-х годов. Известно, что в 1862-1863 гг. работы над этим документом приобрели скандальный характер, поскольку донские общественные деятели обвинили Военное Министерство в нежелании учитывать реальные пожелания казачества. В итоге в состав Донского кодификационного комитета, разрабатывающего «Положение», были введены выборные депутаты.
} 
В Государственном архиве Ростовской области хранится фонд одного из этих депутатов, Х.И. Попова. В нем нам удалось обнаружить рукописи, содержащие критику переданного депутатам на рассмотрение «проекта основных начал Положения о Войске Донском». Мы подробно разбираем эту критику, поскольку она представляет существенный интерес для реконструкции отдельных статей предложенного депутатам текста. Из нее следует, что уже «проект основных начал» носил компромиссный характер, и не соответствовал либеральной политике Военного Министерства начала 1860-х годов.

В результате заседаний депутатов в проект были внесены дополнительные изменения, и получившийся в итоге текст был отправлен в начале 1864 г. в Санкт-Петербург. Однако он не устроил имперское правительство, и работы по составлению «Положения» были фактически прекращены.

Таким образом, «Положение об управлении Донского войска» оказалось настоящим текстом-призраком, искать окончательный вариант которого бессмысленно: хотя работы над ним формально велись почти десятилетие, фактически в это время создавались только предварительные наработки, из которых на цельность и системность могут претендовать только различные редакции «проекта основных начал Положения о Войске Донском».

Ключевые слова: «Положение об управлении Донского войска» 1860-х гг., Донской кодификационный комитет, Х.И. Попов, Д.А. Милютин, преобразования Донского войска 1860-х годов.

Цитирование. Перетятько А. Ю. К истории одного текста: «Положение об управлении Донского войска» 1860 -х годов // Вестник Волгоградского государственного университета. Серия 4, История. Регионоведение. Международные отношения. -2018. - Т. 23, № 2. - С. 100-110. - DOI: https://doi.org/10.15688/jvolsu4.2018.2.8

\section{Введение}

Вероятно, каждому человеку, интересующемуся историей казачества, знакомо хотя бы по названию «Положение об управлении Донского войска», или, как его еще именуют, «Положение о Войске Донском», принятое в 1835 году. Этот документ несколько десятилетий регламентировал почти все стороны жизни донского казачества, несмотря на то что на Дону он с самого начала вызывал очевидное неприятие, и уже на торжественную церемонию его «открытия» в Новочеркасске не явились многие местные генералы [17, p. 108 109]. Куда менее известно, что на рубеже 1850 1860 гг. Военное Министерство предприняло попытку заменить это «Положение» новым, более соответствующим изменившимся реалиям Российской империи [7, с. 263].

История органа, на который была возложена миссия по составлению нового документа, относительно изучена. Донскому кодификационному комитету посвящены отдельные статьи Р.Г. Тикиджьяна [13] и А.А. Волвенко [2]. Однако исследователям так и не удалось обнаружить ни одного полного варианта «Положения» [1, с. 17]. Между тем история самого текста, пусть и не воплощенного в реальные законоположения, в данном случае представляется нам не менее важной, чем история комитета, этот текст писавшего. Дело в том, что новый проект
«Положения об управлении Донского войска» имел несколько предварительных вариантов, каждый из которых отражал позицию совершенно конкретной политической или общественной силы. До наших дней дошли критические отзывы на эти варианты, исходящие как сверху, от центральных министерств, так и снизу, от выборных станичных депутатов. Целый ряд этих отзывов хранится в фонде известного донского историка и общественного деятеля Х.И. Попова в Государственном архиве Ростовской области (далее - ГАРО). С их помощью мы хотим попытаться понять, как велась работа над «Положением об управлении Донского войска», и выяснить, имеет ли смысл вообще искать окончательную редакцию этого документа.

\section{Методы}

Поскольку нами вовлекаются в научный оборот прежде неизвестные историкам архивные материалы, мы будем широко использовать историко-описательный метод. Однако для выполнения задач нашего исследования его недостаточно: и эти архивные материалы, и опубликованные свидетельства современников, и статьи современных историков раскрывают только отдельные аспекты подготовки «Положения об управлении Донского войска», не давая целостной картины, и при этом часто противоречат друг другу. По- 
этому, чтобы понять, как шел процесс работы над новым документом, мы применим историко-сравнительный метод и метод исторической реконструкции.

В этом нам поможет целый ряд источников. Прежде всего, следует отметить два документа из фонда Х.И. Попова в ГАРО, в которых содержится наиболее развернутая критика одного из предварительных вариантов «Положения». Речь идет о «Замечаниях депутатов, назначенных от станиц Хоперского округа, на проект основных начал Положения о Войске Донском» [4] и «Черновике проекта "Положения о Войске Донском" $»^{1}$ [14], до сих пор не привлекавших внимание историков. Мы будем использовать и другие материалы из фонда Х.И. Попова, характеризующие деятельность кодификационного комитета и отношение к немуна Дону, а также документы Российского государственного военно-исторического архива (РГВИА), в которых описано, как готовились другие значимые документы, регламентирующие жизнь казачества, в 1860-1870-х годах. Меньшее значение для нашей работы имеют опубликованные источники, в частности, воспоминания Д.А. Милютина [8] и заметки в периодической прессе того времени [5].

\section{Анализ}

Хотя Донской кодификационный комитет начал свою работу в 1860 г., на первом этапе его деятельности мы не будем останавливаться подробно. Дело в том, что, как установил Р.Г. Тикиджьян, комитету, вопреки его первоначальной задаче, почти сразу же было разрешено, «не составляя всего текста нового «Положения», пересылать отдельные проекты уставов по мере их составления» [13, с. 9598]. Да и у самих казаков комитетская работа не вызывала особого интереса: А.А. Волвенко приводит любопытнейшую цитату из письма неизвестного современника, согласно которой «никто, решительно никто не думал, чтоб комиссия (ошибка анонимного автора, имеется в виду Донской кодификационный комитет. - А. П.) имела в глазах правительства серьезное значение, чтоб она могла облегчить судьбу казаков» [2, с. 20-24].

Ситуация резко изменилась с назначением Д.А. Милютина на пост военного министра в 1861 году. Служивший на Кавказе и составивший там вполне определенное представление о казаках генерал уже представлял, какие именно реформы он хочет провести в казачьих войсках, и не особенно собирался учитывать чье-либо мнение по этому вопросу. Поэтому новый министр сразу попытался пересмотреть роль местных комитетов, официально сведя ее к простой адаптации некоей «общей программы, в которой были бы установлены общие начала для всех Положений» ${ }^{2}$. Разрабатывать эту программу было поручено центральному аппарату Военного Министерства, а контроль над этим процессом осуществлял Н.И. Карлгоф, давний сподвижник Д.А. Милютина [15, p. 1406-1411].

Подобный централизаторский подход вступил в слишком уж явное противоречие с либеральной риторикой как самого министра, так и окружавших его военных чиновников. В 1862 г. офицер для особых поручений при Н.И. Карлгофе, И.Д. Попко, выступил в печати со статьей «О преобразованиях в казачьих войсках», правда, не под собственным именем, а под псевдонимом «Есаул» [1, с. 15]. В этой статье, помимо всего прочего, рисовалась без преувеличения идиллическая картина работы кодификационных комитетов, якобы составленных из самих казаков, опирающихся на мнение народа, и представляющих собой полноценные общественные органы [6, л. 1 об.]. О том, какую реакцию вызывали подобные тексты на Дону, можно судить по тому, что Х.И. Попов посвятил целую рукопись развернутому критическому ответу на публикацию И.Д. Попко. Донской автор с негодованием отмечал, что в действительности кодификационные комитеты хотя и включали в себя казаков, но казаков, назначенных властями, и обязанных выполнять распоряжения вышестоящих чиновников [6, л. 1 об.-2]. Х.И. Попов напоминал своим читателям, что и непопулярное «Положение об управлении Донского войска» от 1835 г. формально писалось с участием представителей казачества, но это не помешало военному министру А.И. Чернышеву отстранить от работы над его текстом всех людей, «мнение которых не нравилось ему». И в конце оппозиционный общественный деятель ехидно сравнивал либеральное руководство Военного Министерства 1860-х гг. с оди- 
озным николаевским министром, задавая вполне логичный вопрос: «Зачем повторять зады в наше время, гордящееся своей прогрессивностью?» [6, л. 2 об.-3].

Как мы видим, реальные действия Военного Министерства никак не соответствовали публично декларируемой им политике, а донские консерваторы, выступавшие за сохранение исторических привилегий Донского войска, требовали следовать этой политике, допустив до работы в Донском кодификационном комитете выборных депутатов. И в 1863 г., в рамках общей политики «умиротворения» казачества, имперские власти пошли на уступки. В состав Донского кодификационного комитета, прежде состоявшего из четырех назначенных атаманом членов, было включено «по одному представителю от донских дворян, торговых и рядовых казаков». Что еще важнее, новый состав комитета получил задание отвлечься от составления локальных уставов, регламентирующих отдельные стороны жизни казачества, и подготовить, наконец, единый «проект основных начал Положения о Войске Донском», который должен был пройти обсуждение как имперскими министрами, так и выборными депутатами от всего казачества [13, с. 95-98].

Вот что писал по этому поводу И.И. Краснов, один из немногих донских генералов, поддерживавших правительственную политику начала 1860-х гг.: «Атаман исходатайствовал высочайшее разрешение избрать в каждом из семи гражданских округов Донского войска по одному члену или депутату от дворян, по одному от беспоместных чиновников, и по одному от каждой из 108 станиц войска; выбранные члены должны были собраться в 1863 г. в Новочеркасске на два месяца (как следует из дальнейшего текста, в ноябре декабре. - А. П.) и пересмотреть уже составленный бывшими членами комитета проект с полною свободой изменять и дополнять оный по общему согласию, или, в случае не состоявшегося согласия, представлять отдельные мнения» [5, с. 350-351]. Сами депутаты (по крайней мере, от Хоперского и Усть-Медведицкого округов) определяли свои задачи следующим образом: «заявить свои мнения относительно тех статей, кои не будут соответ- ствовать по нашему разумению справедливым пользам и желаниям казачьего сословия (курсив наш. - А. П.), а также заявить и другие современные нужды и потребности, кои не введены в проект главных оснований ${ }^{3}$, но необходимы будут для соображений при дальнейшем составлении полного проекта Положения» $[4$, л. 1 об.]. Уже из этой формулировки видно, что депутаты заняли консервативную, «казакоманскую» позицию, и во главу угла ставили свои сословные интересы.

В Донской кодификационный комитет поступали уже готовые своды рекомендаций от собрания депутатов каждого округа. К сожалению, нам удалось обнаружить только два подобных документа, о которых мы уже упоминали выше, и которые хранятся в фонде Х.И. Попова. Можно предположить, что они оказались там потому, что донской историк и публицист был выбран депутатом от одной из хоперских станиц [3, с. 409], а среди черкасских депутатов особым авторитетом пользовался его хороший знакомый, И.П. Прянишников [3, с. 420]. Как мы уже отмечали, эти два общественных деятеля сыграли значительную роль в подготовке сводов рекомендаций от своих округов, и, видимо, участвовали в их редакции, сохранив при этом первоначальные черновики [16, p. 374].

Имеет смысл подробнее остановиться на тех изменениях, которые предлагали внести в «проект основных начал Положения о Войске Донском» представители Черкасского округа (аналогичный текст представителей Хоперского округа слишком обширен и богат фактографическим материалом, чтобы проанализировать его в небольшой статье). Поскольку ни один из вариантов самого «проекта основных начал» до сих пор не найден (или, по крайней мере, не вовлечен в научный оборот), эта информация будет полезна, чтобы в дальнейшем частично реконструировать его первоначальный текст и понять, какие в него вносились изменения.

1) Статьи 19 и 20. Черкасские избранники требовали, чтобы любые сборы со станиц утверждались не только правительственными чиновниками, но и депутатами от этих станиц, а также от местного дворянства $[14$, л. 11 об.]. Схожее предложение было сделано и хоперскими представителями [4, л. 2-2 об.]. 
2) Статья $44{ }^{4}$. Предлагалось запретить вносить изменения в новое "Положение об управлении Донского войска» без разрешения депутатов от всего донского казачества $[14$, л. 2]. В хоперском своде по этому поводу сказано следующее: «Желательно, чтобы в проект положения виисано было, что всякое изменение в положении этом, касательно образа службы, владения землею и других прав и привилегий, дарованных войску Монархами, на будущее время должно согласовываться с участием депутатов всего войска» [4, л. 79-79 об.].

3) Статья 56. В первоначальной редакции эта статья разрешала выход из казачьего сословия, что вызвало неудовольствие черкасских депутатов, требовавших запретить подобный выход и изменить смысл статьи на противоположный [14, л. 2 об.]. И снова хоперцы поддержали их, особо подчеркивая, что «казаки дорожат правами и привилегиями, приобретенными долговременными заслугами», и не хотят, чтобы существовала даже теоретическая возможность их потери [4, л. 5-6 об.].

4) Статья 66. Рекомендовалось ввести единый налог для членов донского торгового общества [14, л. 2 об.-3]. Аналогичное предложение, вплоть до сумм выплат, было сделано и хоперскими представителями $[4$, л. 9-9 об.].

5) Статья 74. Черкасские депутаты настаивали на том, что при занятии иерковных должностей на территории Земли Войска Донского казаки должны были иметь преимущество перед неказаками. Кроме того, прихожанам предлагалось дать право утверждать священнослужителей [14, л. 3-4]. Первая из этих идей содержится и в своде рекомендачий Хоперского округа, причем ей уделено серьезное внимание [4, л. 21-23 об.].

6) Статья 77. Изначально данная статья разрешала иногородним приобретать недвижимость в пределах Донского войска. И черкасские, и хоперские депутаты потребовали изменить ее смысл на противоположный, доказывая, что казачье сословие не желает видеть на своей земле иногородних-собственников [4, л. 24-26; 14, л. 4 об.-5].
7) Статья 94. Эта статья касалась вопросов пользования сенокосами и виноградниками. Незначительные редакционные изменения, рекомендованные для нее черкасскими депутатами [14, л. 5-5 об.], не имеют аналогов в хоперском тексте.

8) Статьи 114 и 116. Представители Черкасского округа призывали ужесточить законодательство, препятствующее получению иногородними земельной собственности на Дону. Хотя уже первоначальная редакция статей запрещала продажу иногородним земли, депутаты считали нужным ограничить так же передачу этой земли по наследству [14, л. 5 об.-6 об.]. Хоперцы избрали иную тактику: они, напротив, требовали оставить в неприкосновенности данную часть «проекта главных оснований», опасаясь, что в результате ее редактирования возобладает мнение некоторых помещиков, «желающих продавать иногородним земли» [4, л. 16-16 об.].

9) Главы XXXIII и XXIV. Предлагалось полностью исключить из текста «Положения» главы об окружных дежурствах, подчинив станицы в военном отношении напрямую новочеркасской администрации [14, л. 7-9]. Черкасских депутатов снова поддержали хоперские, правда, предлагая несколько иные способы взаимодействия станичных властей с войсковыми по военной части [4, л. 37-39].

10) Статья 266. Представители Черкасского округа рекомендовали узаконить традиционный статус молодых казаков, которые на время подготовки к службе освобождались от всех повинностей $[14$, л. 9]. Этот пункт, как и два следующих, не имеет аналогий в своде рекомендаций от Хоперского округа.

11) Статья 281. По мнению выборных от черкасских станиц, следовало назначать офицеров в гвардейские полки по общевойсковому списку вакансий, чтобы одна часть офицерского корпуса не получала преимуществ над другой [14, л. 9 об.].

12) Статья 310. По поводу возможного введения на Дону гражданских чинов в документе написано: «Они (гражданские чины. A. П.) противоречат нашей жизни, потому что не могут быть подведены под общий закон обязательной службы» [14, л. 9-9 об.]. Соответственно, статью 310 , изначально посвященную статусу людей, состоящих в этих чинах, следо- 
вало переписать: новая версия предполагала автоматическое получение всеми чиновниками соответствующих военных званий [14, л. 9 об.].

13) Статья 314. Зато в данном случае мнения черкасских и хоперских депутатов снова совпали: рекомендовалось облегчить получение разрешений на отлучки из станицы казакам, состоящим на службе. В новой редакции эти разрешения должны были выдавать станичные правления, а не войсковое дежурство [4, л. 44; 14, л. 10].

14) Статья 324. Представители черкасского округа шли еще дальше в расширении полномочий станичных правлений: они считали необходимым передать им и функции освобождения от службы больных и увечных казаков. Профессиональные врачи для медицинского освидетельствования могли бы приглашаться только по инициативе этих правлений [14, л. 10].

15) Статья 332. Если предыдущее предложение черкассцев не нашло поддержки у представителей Хоперского округа, то здесь депутаты были единодушны: следовало дать станичным обществам право освобождать от службы тех призывников, «чьи семейства оставались вовсе без средств к существованию» [4, л. 46; 14, л. 10 об.]. Кстати, это последний пункт, по которому мнения представителей двух округов сошлись.

16) Статья 337. Представители Черкасского округа соглашались с тем, что казак должен приобретать лошадь за свой счет. Однако они находили справедливым, чтобы, в случае убыли двух таких лошадей, третья покупалась уже за счет войска [14, л. 10 об.].

17) Статья 379. Депутаты требовали уравнять оклады казачьих офицеров с офицерами регулярных частей. Поскольку обоснование этого шага достаточно любопытно, и проливает свет на некоторые проблемы Донского войска, мы выпишем его полностью. «На недостаток жалования жалуются как войсковые, так и станичные должностные лица. Вследствие этого недостатка должности не всегда занимаются лицами, способными занять оные, а занимаются большею частью людьми, смотрящими на должность, как на доходную статью» [14, л. 10 об.].

Мы видим, что разработанный членами Донского кодификационного комитета «проект основных начал Положения о Войске Донском» был подвергнут станичными депутатами серьезной критике, причем по ключевым вопросам представители разных округов придерживались схожих позиций. Но, как ни парадоксально, из этой критики следует, что уже его первоначальный текст не был плодом официальной правительственной политики, и как минимум в одном пункте принципиально противоречил спущенной сверху «общей программе» для Положений в казачьих войсках. В разработанном Н.И. Карлгофом документе предусматривалось «дозволение водворяться в казачьих пределах людям всех состояний, без зачисления в казачье гражданство и приобретать недвижимую собственность» [1, с. 15]. На первый взгляд, «Проект основных начал» содержал соответствующую статью 77, для которой нам известна даже дословная формулировка: «Во всех станицах войска постройка домов, фабрик, заводов, вообще торговых заведений, а равно приобретение существующих уже там подобных строений, дозволяется иногородним лицам, с платою ежегодно поземельной пошлины в станичный доход» [4, л. 24]. Однако затем следовали статьи 112 и 114, запрещающие продажу иногородним земли, что создавало своеобразный логический парадокс: в рамках подобного законодательства покупать недвижимость на Дону иногородние уже могли, но продавать им эту недвижимость все еще было нельзя. На наш взгляд, такое противоречие свидетельствует о том, что новый состав Донского кодификационного комитета пытался найти какой-то компромисс, лавируя между требованиями правительства и настроениями в казачьей среде. Увы, созданный в итоге текст даже безо всякой правки станичными депутатами оказался бы неприемлем для центральной власти, поскольку у министра внутренних дел Российской империи П.А. Валуева вызывала крайнее возмущение сама идея ограничения прав иногородних на приобретение недвижимости, как «противоречащая понятию собственности (подчеркнуто П.А. Валуевым. А. П.)» [2, с. 20-24].

Двойственная позиция Донского кодификационного комитета, большинство в котором все еще составляли назначенные атаманом члены, не должна вызывать удивления. В 1860-х гг. консервативные настроения были 
широко распространены в донских офицерских кругах, и даже председатель комитета, Федор Иванович Шумков, вызывал в этом отношении серьезные подозрения у Военного Министерства. Помощник Н.И. Карлгофа, А.П. Чеботарев, давал ему следующую характеристику: «Отставной генерал-майор Шумков получил образование в Артиллерийском училище, известен как достойный человек по своим правилам и как храбрый офицер в военное время, по убеждениям же своим принадлежит к партии Донцов, желающих замкнутости войска (курсив наш. A. П.)» $[18$, р. 39]. И в итоге комитетское большинство прислушалось к замечаниям выборных депутатов, хотя и неизвестно, в какой степени. Об этом можно судить потому, что в 1864 г. в Санкт-Петербург для дальнейшей корректировки был отправлен уже измененный «проект основных начал Положения о Войске Донском» ${ }^{5}$. В своде рекомендаций хоперских депутатов критикуется статья 339 предложенного им текста, посвященная организации практических занятий казаков-артиллеристов [4, л. 46 об.]. Между тем после получения донского проекта имперскими властями, П.А. Валуев выражал крайнее неудовольствие статьей с тем же номером, но уже совершенно иного содержания: в ней к обязанностям поземельного отделения было отнесено «охранение неприкосновенности войсковых границ», в чем высокопоставленный чиновник увидел «желание поддержать принцип обособления края» [1, с. 18].

В любом случае работа Донского кодификационного комитета в 1864 г. не прекратилась. Более того, нами в ГАРО найден документ, из которого следует, что еще 7 мая 1865 г. комитет продолжал рутинную работу по уточнению отдельных деталей «Положения» $[10$, л. 1]. Тут было бы уместно напомнить, что выборные депутаты в 1863 г. собирались менее чем на два месяца, и, по выражению И.И. Краснова, успели сделать столько, «сколько можно было успеть в течение этого времени», оставив зато ряд «отдельных мнений» по спорным вопросам, вроде тех, что мы обнаружили в фонде Х.И. Попова [5, с. 350-351]. Отправленный же в Санкт-Петербург документ, судя по его названию, оценивался как предварительный. Соответственно, требовалась его дальнейшая доработка, причем ее можно было осу- ществлять с учетом не только пожеланий центральных министерств, но и доработанных сводов рекомендаций выборных депутатов и мнений членов Донского кодификационного комитета. Схожим образом велась работа, например, над подготовкой военных реформ на Дону в 1870-х гг.: уже после отправки в СанктПетербург материалов комиссии, подготавливавшей предварительный проект реформы, ее отдельные положения уточнялись местными властями, и окончательный проект, составленный уже в Военном Министерстве, учитывал их пожелания [9, л. 1-59].

Однако события быстро начали развиваться по иному сценарию. «Проект основных начал Положения о Войске Донском» вызвал в Санкт-Петербурге откровенное разочарование и был подвергнут уничтожающей критике. Д.А. Милютин писал об этом: «Новочеркасский комитет представил проект, проникнутый духом замкнутости, обособленности, старинных привилегий казачества, без всякого внимания к новым преобразованиям в государстве. Такой проект очевидно показал, что вести столь важное дело на местах в среде самого казачества было невозможно без общего руководительства центральной власти» [8, с. 184-185]. В полном соответствии со словами военного министра 2 октября 1865 г. были утверждены «Временные правила о порядке рассмотрения и утверждения проектов новых положений о казачьих войсках», согласно которым эти положения должны были дорабатываться не местными комитетами, а специально создаваемым органом при Управлении иррегулярных войск, Временным комитетом по пересмотру казачьих законоположений [13, с. 95-98]. А Н.И. Карлгоф, назначенный руководителем Временного комитета и получивший задание составить программу его работ, сумел в элегантном бюрократическом стиле избежать рассмотрения написанных местными комитетами проектов «Положений», «положить их под сукно», по выражению С.Г. Сватикова [11, с. 348]. В программе работ Временного комитета генерал писал: «Подвергать составленные местными Комитетами проекты новых Положений о казачьих войсках во всей подробности один за другим было бы, по мнению моему, неудоб- 
но по следующим причинам: во-первых, если не будут предварительно установлены общие для всех казачьих войск основные законоположения, то необходимо будет возвращаться к ним при пересмотре каждого нового Положения, а во-вторых, было бы несправедливо заставлять казачьи войска, о которых Положения пришлось бы рассматривать в последних очередях, ожидать разрешения существенно важных для всего казачества вопросов» [12, с. 413]. Соответственно «Проект основных начал Положения о Войске Донском» не был отвергнут публично, но работы над ним прекратились якобы из-за изменения системы делопроизводства. Вскоpe, в 1866 г., был закрыт и непокорный Донской кодификационный комитет (ему, впрочем, было дано довести свою работу до конца, передав в Санкт-Петербург целый ряд проектов, регламентирующих отдельные стороны жизни казачества) [13, с. 95-98]. Вот только теперь, когда они не были сведены в единый текст, Временный комитет мог рассматривать их в том порядке, который показался бы Н.И. Карлгофу наиболее удобным, или не рассматривать вообще. И, хотя формально работы над данным документом продолжались едва ли не до 1872 г., когда был де-факто распущен Временный комитет по пересмотру казачьих законоположений $[12$, с. $426-$ 427], фактически Военное Министерство вернулось к практике, принятой до 1863 г., когда вместо единого текста, регламентирующего все стороны жизни казачества, разрабатывались отдельные законоположения и уставы [1, с. 17-18].

\section{Результаты}

«Положение об управлении Донского войска» 1860-х гг. оказалось документом с удивительной судьбой. Хотя Военное Министерство все десятилетие декларировало, что над ним ведется активная работа, единственная попытка составить его единый текст была предпринята в 1863-1864 годах. До этого Донской кодификационный комитет занимался подготовительной работой, создавая проекты локальных актов, соединять которые воедино, возможно, планировало само Военное Министерство, в 1861-1862 гг. пред- принявшее попытку свести роль комитета до простой адаптации к местным реалиям спущенных сверху указаний.

И в итоге именно централизаторская политика Военного Министерства, не соответствующая публичным декларациям военных чиновников, спровоцировала конфликт имперских властей и местной общественности. Чтобы снизить его напряженность, имперская власть пошла на уступки: в 1863 г. в состав Донского кодификационного комитета были введены представители различных субсословных групп казачества, а комитету в целом было поручено самостоятельно составить единый «проект основных начал Положения о Войске Донском». Уже к ноябрю того же года была готова первая редакция этого текста, представлявшая собой попытку компромисса между требованиями правительства и позицией консервативного казачьего большинства. Однако она не устроила выборных депутатов от станиц и донского дворянства, желавших сохранить замкнутость казачьего сословия и расширить его привилегии, например, запретив менять основополагающие законоположения о Донском войске без разрешения его выборных представителей. С учетом их пожеланий была составлена новая, вторая, редакция «проекта основных начал», в 1864 г. отправленная в Санкт-Петербург, где неприятие этого текста правительственными чиновниками окончательно превратило «Положение» из реально разрабатываемого документа в бюрократический фантом.

Судя по реконструированной нами хронологии, окончательный, беловой вариант «Положения об управлении Донского войска» 1860 -х гг. так и не был разработан. Вторая редакция «проекта основных начал Положения о Войске Донском», которую считают подобным документом С.Г. Сватиков и А.А. Волвенко, на самом деле была только одной из предварительных версий, не учитывающей не только мнение имперских властей, но и часть пожеланий станичных депутатов. Если мы правы, то «Положение об управлении Донского войска» можно считать в прямом смысле этого слова текстом-призраком, который породил массу других интереснейших документов, но при этом сам так и не был написан. 


\section{ПРИМЕЧАНИЯ}

${ }^{1}$ Название не соответствует действительности: эта рукопись содержит критику все того же «проекта основных начал Положения о Войске Донском» депутатами Черкасского округа.

2 Этот текст получил название «Соображения учрежденного при Управлении иррегулярных войск комитета о главных началах, которые должны быть приняты в руководство при составлении новых положений о казачьих войсках».

3 «Проект основных начал Положения о Войске Донском» в этом и ряде других документов так же именуется «проектом главных оснований Положения о Войске Донском». А.А. Волвенко приводит и третий вариант названия: «проект “основных начал” нового Положения о войске Донском». Судя по всему, общеупотребительного названия данного текста так и не было выработано.

${ }^{4}$ Курсивом мы выделили те статьи, которых не было в первоначальном тексте, и которые предлагали ввести черкасские депутаты.

5 Впрочем, некоторые авторы утверждают, что в начале 1864 г. в Военное Министерство был направлен уже «проект нового положения о войске Донском». Об этом пишут С.Г. Сватиков [11, c. 348] и, в некоторых своих работах, А.А. Волвенко [1, с. 17-18]. Однако в этом случае непонятно, когда Донской кодификационный комитет успел составить подобный окончательный проект: заявление И.И. Краснова о том, что последние заседания выборных депутатов происходили в декабре 1863 г., подтверждается и архивными источниками, в которых одно из заседаний хоперских представителей датируется 3 декабря [4, л. 79]. Кроме того, сам А.А. Волвенко в другой своей статье именует этот же текст «проектом “основных начал” нового Положения о войске Донском» [18, p. 39].

\section{СПИСОК ЛИТЕРАТУРЫ}

1. Волвенко, А. А. Донское казачество в правительственной политике эпохи «Великих реформ» (1860-1870 гг.) / А. А. Волвенко // Известия Самарского центра Российской академии наук. - 2014. T. 16, № 3. - С. 12-20.

2. Волвенко, А. А. Нереализованный проект Положения о войске Донском / А. А. Волвенко // Научная мысль Кавказа. - 2006. - № 1. - С. 20-24. $599 \mathrm{c}$

3. Донцы ХІХ века. - Ростов н/Д : NB, 2003.-

4. Замечания депутатов, назначенных от станиц Хоперского округа, на проект основных начал Положения о Войске Донском // Государственный архив Ростовской области (ГАРО). - Ф. 55. - Оп. 1. Д. 240. -89 л.

5. Краснов, И. И. Беспоместные и мелкопоместные чиновники войска Донского / И. И. Краснов // Русский вестник. - 1865. - Т. 58. - С. 329-351.

6. Критика статьи «О преобразованиях в казачьих войсках», напечатанной в «Русском вестнике» за № 8 // Государственный архив Ростовской области (ГАРО). - Ф. 55. - Оп. 1. - Д. 34. - 16 л.

7. Милютин, Д. А. Воспоминания генералфельдмаршала графа Дмитрия Алексеевича Милютина. 1860-1862 / Д. А. Милютин. - М. : Российский архив, 1999. -559 с.

8. Милютин, Д. А. Воспоминания генералфельдмаршала графа Дмитрия Алексеевича Милютина. 1865-1867 / Д. А. Милютин. - М. : РОССПЭН, 2005. $-696 \mathrm{c}$.

9. О воинской повинности Донского казачьего войска // Российский государственный военноисторический архив (РГВИА). - Ф. 330. - Оп. 61. Д. 1937. - 72 л.

10. Особое мнение членов комитета для составления проекта положения о Войске Донском войсковых старшин Павлова и Курочкина и урядника Попова к протоколу комитета // Государственный архив Ростовской области (ГАРО). - Ф. 55. - Оп. 1. Д. 285. -4 л.

11. Сватиков, С. Г. Россия и Дон (1549-1917 гг.) / С. Г. Сватиков. - Белград : Издание Донской Исторической Комиссии, 1924. - 592 с.

12. Столетие военного министерства. 18021902. - СПб. : Синодальная типография, 1902.- Т. ХІ, ч. $1 .-973 \mathrm{c}$.

13. Тикиджьян, Р. Г. Донской кодификационный комитет / Р. Г. Тикиджьян // Донской временник. -2014. - Вып. 23. - С. 95-98.

14. Черновик проекта «Положения о войске Донском» // Государственный архив Ростовской области (ГАРО). - Ф. 55. - ОП. 1. - Д. 70. - 10 л.

15. Peretyatko, A. Y. "Before Giving to the Nation or Tribe A New Order, One Must First Ask the People of this Nation whether they Need this Order": the Local Prerequisites for the Reforms of 1860-1870 On the Don. Part II / A. Y. Peretyatko // Bylye Gody. - 2017. - Vol. 46, iss. 4. - P. 1401-1415. - DOI: 10.13187/bg.2017.4.1401.

16. Peretyatko, A. Y. Higher and Secondary Education of the Don Cossacks in the Context of the Epoch: the Time of the Great Reforms / A. Y. Peretyatko, T. E. Zulfugarzade// European Journal of Contemporary Education. - 2017. - Vol. 6 (2). - P. 367-377. - DOI: 10.13187/ejced.2017.2.367.

17. Volvenko, A. A. Chebotarev, A.P. - "the Grey Cardinal" of Cossack Reforms of the Epoch of Liberation? / A. A. Volvenko. // History and Historians in the Context of the Time. - 2015. - Vol. 15, iss. 2.P. 106-114. - DOI: 10.13187/hhct.2015.15.106. 
18. Volvenko, A. A. Don Atamans of the Age of "Great Reforms" (the 1860s-1870s) / A. A. Volvenko. // Russkaya Starina. - 2017. - Vol. 8 (1). - P. 34-54. DOI: $10.13187 /$ rs.2017.1.34.

\section{REFERENCES}

1. Volvenko A.A. Donskoe kazachestvo v pravitelstvennoy politike epokhi «Velikikh reform» (1860-1870 gg.) [The Don Cossacks in the Governmental Policy in the Age of Great Reforms (the 1860-1870s)]. Izvestiya Samarskogo tsentra Rossiyskoy akademii nauk, 2014, vol. 16, iss. 3, pp. 12-20.

2. Volvenko A.A. Nerealizovannyy proekt Polozheniya o voyske Donskom [Unrealized Project of the Regulation on the Don Host]. Nauchnaya mysl Kavkaza, 2006, no. 1, pp. 20-24.

3. Dontsy XIX veka [Don Cossacks of the $19^{\text {th }}$ c.]. Rostov-on-Don, NB Publ., 2003. 599 p.

4. Zamechaniya deputatov, naznachennykh ot stanits Khoperskogo okruga, na proekt osnovnykh nachal Polozheniya o Voyske Donskom [Remarks of Deputies Appointed from the Villages of the Khopersky District to the Draft of the Basic Principles of the Regulation on the Don Host]. Gosudarstvennyy arkhiv Rostovskoy oblasti [State Archive of the Rostov Region], F. 55, Op. 1, D. 240, 891.

5. Krasnov I.I. Bespomestnye i melkopomestnye chinovniki voiska Donskogo [Landless and SmallLanded Officials of the Don Host]. Russkiy vestnik, 1865, vol. 58, pp. 329-351.

6. Kritika statyi «O preobrazovaniyakh v kazachyikh voyskakh», napechatannoi v «Russkom vestnike» za № 8 [Criticizm of the Article "About Reforms in the Cossack Hosts", Published in the Russian Herald no. 8]. Gosudarstvennyy arkhiv Rostovskoy oblasti [State Archive of the Rostov Region], F. 55, Op. 1, D. 34, 161.

7. Milyutin D.A. Vospominaniya generalfeldmarshala grafa Dmitriya Alekseevicha Milyutina. 1860-1862 [Memoirs of General Field Marshal, Prince Dmitry Alekseevich Milyutin. 1860-1862]. Moscow, Russkiy arkhiv Publ.,1999. 559 p.

8. Milyutin D.A. Vospominaniya generalfeldmarshala grafa Dmitriya Alekseevicha Miliutina. 1865-1867 [Memoirs of General Field Marshal, Prince Dmitry Alekseevich Milyutin . 1865-1867]. Moscow, ROSSPEN Publ., 2005. 696 p.
9. O voinskoy povinnosti Donskogo kazachyego voyska [About the Military Service of the Don Cossack Host]. Rossiyskiy gosudarstvennyy voenno-istoricheskiy arkhiv [Russian State Military and Historical Archive], F. 330, Op. 61, D. 1937, 721.

10. Osoboe mnenie chlenov komiteta dlya sostavleniya proekta polozheniya o Voiske Donskom voyskovykh starshin Pavlova i Kurochkina $i$ uryadnika Popova k protokolu komiteta [A Special Opinion of the Members of the Committee for Drawing up a Draft of the Regulation of the Don Host by Leaders Pavlov and Kurochkin and Sub-officer Popov to the Protocol of the Committee]. Gosudarstvennyy arkhiv Rostovskoy oblasti [State Archive of the Rostov Region], F. 55, Op. 1, D. 285, 41.

11. Svatikov S.G. Rossiya i Don (1549-1917 gg.) [Russia and the Don (1549 - 1917)]. Belgrade, Izdanie donskoy istoricheskoy komissii, 1924. 592 p.

12. Stoletie voennogo ministerstva. 1802-1902 [Century of the Ministry of Defence of 1802-1902]. Saint Petersburg, Synodalnaya tipografiya, 1902, vol. XI, part 1.973 p.

13. Tikidzhian R.G. Donskoy kodifikatsionnyy komitet [Don Codification Committee]. Donskoy vremennik, 2014, vol. 23, pp. 95-98.

14. Chernovik proekta «Polozheniya o voyske Donskom» [The Draft Project of the Regulation of the Don Host]. Gosudarstvennyy arkhiv Rostovskoy oblasti [State Archive of the Rostov Region], F. 55, Op. 1, D. 70, 101.

15. Peretyatko A.Yu. "Before Giving to the Nation or Tribe a New Order, One Must First Ask the People of this Nation whether they Need this Order": the Local Prerequisites for the Reforms of 1860-1870 on the Don. Part II. Bylye Gody, 2017, vol. 46, iss. 4, pp. 1401-1415. DOI: $10.13187 /$ bg.2017.4.1401.

16. Peretyatko A.Yu., Zulfugarzade T.E. Higher and Secondary Education of the Don Cossacks in the Context of the Epoch: the Time of the Great Reforms. European Journal of Contemporary Education, 2017, vol. 6 (2), pp. 367-377. DOI: 10.13187/ejced.2017.2.367.

17. Volvenko A.A., Chebotarev A.P. "The Grey Cardinal" of Cossack Reforms of the Epoch of Liberation? History and Historians in the Context of the Time, 2015, vol. 15, iss. 2, pp. 106-114. DOI: 10.13187/ hhct.2015.15.106.

18. Volvenko A.A. Don Atamans of the Age of "Great Reforms" (the 1860s - 1870s). Russkaya Starina, 2017, vol. 8 (1), pp. 34-54. DOI: 10.13187/rs.2017.1.34. 


\section{ОТЕЧЕСТВЕННАЯ ИСТОРИЯ}

\section{Information about the Author}

Artem Yu. Peretyatko, Candidate of Sciences (History), International Network Center for Fundamental and Applied Research, Gorkogo St., 89a, office 4, 354000 Sochi, Russian Federation; American Historical Association, SE St., 400a, 20003 Washington DC, USA, ArtPeretatko@yandex.ru, https://orcid.org/0000-0003-2779-2223

\section{Информация об авторе}

Артем Юрьевич Перетятько, кандидат исторических наук, Международный сетевой центр фундаментальных и прикладных исследований, ул. Горького, 89а, офис 4, 354000 г. Сочи, Российская Федерация; Американская ассоциация историков, ул. СЕ, 400a, 20003 г. Вашингтон, США, ArtPeretatko@yandex.ru,https://orcid.org/0000-0003-2779-2223 